\title{
ERRATUM
}

A. Akici · S. Kalaça · M. Z. Gören · A. G. Akkan

A. Karaalp · D. Demir · Ü. Ŭgurlu $\cdot$ Ş. Oktay

\section{Comparison of rational pharmacotherapy decision-making competence of general practitioners with intern doctors}

\section{Eur J Clin Pharmacol (2004) 60:75-82}

In the reference list of this paper, reference 14 [Akici, Kalaca, Ugurlu et al. (2004) Impact of a short postgraduate course...] was incorrectly given. It should read:
Hassan NAGM, Abdulla AA, Bakathir HA, Al-Amoodi AA, Aklan AM, TPGM de Vries (2000) The impact of problem-based pharmacotherapy training on the competence of rational prescribing of Yemen undergraduate students. Eur J Clin Pharmacol 55: $873-876$

The online version of the original article can be found at http:// dx.doi.org/10.1007/s00228-004-0751-2

\footnotetext{
A. Akici · M. Z. Gören · A. Karaalp · D. Demir · Ü. Uğurlu Ş. Oktay

Department of Pharmacology and Clinical Pharmacology,

Marmara University School of Medicine,

Istanbul, Turkey

S. Kalaça

Department of Public Health,

Marmara University School of Medicine,

Istanbul, Turkey
}

A. G. Akkan

Department of Pharmacology and Clinical Pharmacology,

Istanbul University, Cerrahpaşa School of Medicine,

Istanbul, Turkey

Ş. Oktay $(\bowtie)$

Omega-CRO, Tophanelioğlu Cad., Petek Sitesi A5 Blok,

D.9, Altunizade 34718, Istanbul, Turkey

E-mail: suleok@omega-cro.com.tr

Tel.: + 90-216-3390054

Fax: + 90-216-3390056 